HAEMATOLOGICAL CHARACTERISTICS OF CLARIAS GARIEPINUS (BURCHELL 1822) JUVENILES EXPOSED TO DERRIS ELLIPTICA ROOT POWDER

\title{
Olufayo MO
}

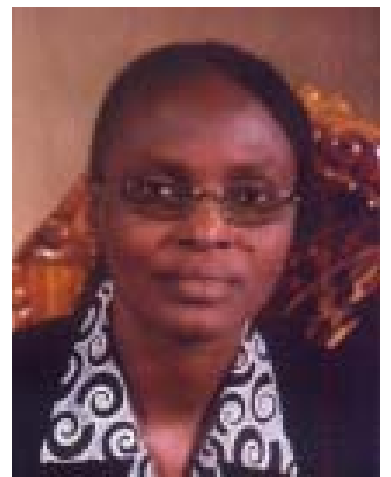

Mosun Olufayo

Corresponding author email: moakinbulumo@yahoo.co.uk

Department of Fisheries and Wildlife, Federal University of Technology Akure, Ondo State, Nigeria. 


\section{ABSTRACT}

In Nigeria, fish farmers have traditionally harvested fish by persistently and indiscriminately abusing the use of natural plant piscicides. In particular Derris elliptica, which contains rotenone which is toxic to fish when it is used in higher concentrations than necessary, causing contamination of fresh water bodies and thereby affecting non target organisms.

Toxicity studies of Derris elliptica root powder were carried out with juveniles of Clarias gariepinus using sublethal concentrations of the root extracts Derris elliptica in $96 \mathrm{~h}$ static bioassay. Estimated numbers of healthy C. gariepinus juveniles were obtained from artisanal fishermen in Ondo State, Nigeria and were transported to the Federal University of Technology, Akure. The $96 \mathrm{~h} \mathrm{LC} 50$ of Derris elliptica to juveniles of $C$. gariepinus was observed to be $15.0 \mathrm{~g} / \mathrm{ml}$. Behavioural activities such as erratic swimming, loss of reflex, hyperventilation, increased surfacing frequency and jerky movements were observed. Values of some haematological parameters of $C$. gariepinus juveniles were analysed to determine the influence of D. elliptica root powder on the test fish. The range values obtained for the Packed Cell Volume (PCV), Haemoglobin (Hb), Erythrocyte (RBC) for $C$. gariepinus in higher concentration of $D$. elliptica root powder were significantly higher; PCV $40.0 \%$ $45.0 \%, \mathrm{Hb} 12.8-14.3 \mathrm{~g} / 100 \mathrm{ml}$, RBC count $38.5-47.4 \times 10^{6} \mathrm{~mm}^{3}$ than those obtained for Clarias in lower concentrations :PCV $25.0-31.2 \%, \mathrm{Hb} 8.3-$ $9.8 \mathrm{~g} / 100 \mathrm{ml}$, RBC count $21.6-32.96 \times 10^{6} \mathrm{~mm}_{2}{ }^{3}$ respectively. Erythrocyte Sedimentation Rate (ESR) decreased than those obtained at lower concentrations of the powder. Erythrocyte Sedimentation Rate (ESR) decreased with increase in $D$. elliptica concentrations. The increase in PCV with increase in $D$. elliptica concentration indicated positive absorption of Derris solution by the fish while the increase of haemoglobin concentration $(\mathrm{Hb})$ and Erythrocyte count (RBC) in $C$. gariepinus at higher concentration of $D$. elliptica may be associated with erythrocytes synthesis.

Key words: Clarias gariepinus, haematology, root-powder, Derris elliptica, sublethal 


\section{INTRODUCTION}

Piscicides are often used to control competing species in fish production especially in small water bodies/enclosures, eradicate fish to control parasites, and conserve or restore native species but their uses are not encouraged because of their toxicity to aquatic organisms and the degradation of the environment. The introduction of most chemicals into the aquatic environment occurs both directly and indirectly and the accumulative non lethal effect of the toxicants on aquatic organisms is extremely hazardous to fish.

Haematological study is important for toxicological research, environmental monitoring of fish and their health conditions during culture because fish generally are so intimately associated with the aquatic environment. Rotenone is the most widely used piscicides in the U SA and its toxicity to North American fishes is well documented [1]. Bio-degradable alternatives (ichthyotoxic plants) are, therefore, preferred to remove unwanted fish and other aquatic species from water bodies. Many plants have medicinal properties and they have been used as base chemicals in pharmaceutical industries and these have been documented [2].

There are many indigenous sources of botanical fish toxicants in Nigeria that are extremely toxic to a wide range of animals including fish; some of these plants include :Derris elliptica, Tephrosia vogelii, Acacia pennata, Tetraplera tetraptera, Mundulea sericea, Boerhavia coccinea. The deliberate introduction of these plant extracts in the aquatic ecosystems could eventually lead to physiological stress in aquatic organisms and ultimately reduction in aquatic productivity [3].

Many plants contain chemicals which have traditionally been used to harvest fish in almost all parts of the world [4]. The best known plant species is Derris elliptica. It contains rotenone $\left(\mathrm{C}_{23} \mathrm{H}_{22} \mathrm{O}_{6}\right)_{2}$, which is toxic to fish. Over 80 species of Derris are distributed mainly in the tropics of south -East Asia and they are known to contain mainly rotenone. They possess insecticidal properties. Rotenone is a chemical that has insecticidal and piscicidal properties [5]. D. elliptica belongs to the family Papilionacea/Leguminosae and has been used for predator control in ponds [6] and its root contains $4 \%$ rotenone [7 ]. Derris is an indigenous plant of Burma, Thailand, Malaysia and the plants are cultivated in the Philippines, Tanzania, Zaire and parts of Northern Nigeria. The local names are 'Aker- tuba', 'Tubli', 'Suy-olo', cube . The active constituents of Derris root powder are soluble in acetone, benzene, chloroform ,ether and in some other organic solvents; they are slightly soluble in alcohol but insoluble in water, weak in acids and in alkalis. It acts as a contact poison and damages the respiratory system of the fish as well as causing death consequently, thus, wash residues should not be allowed to drain into rivers or ponds. Derris root powder is readily available for use, less expensive, stable in water, and is effective in killing the target organisms. It is effective in the control of ecto-parasites of domestic animals.

Fish farmers in Nigeria have persistently and indiscriminately abused these natural plant piscicides by using much higher concentrations than necessary, causing mass

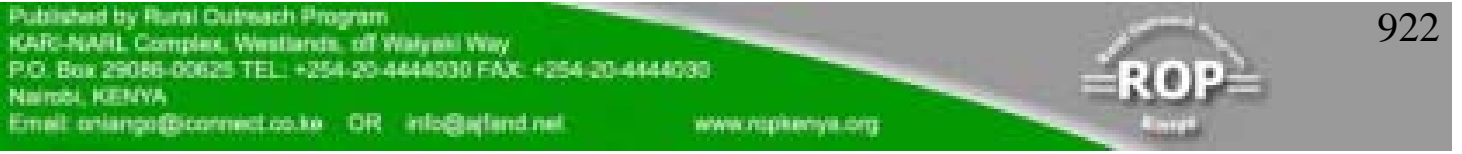


mortality of fish in ponds, contaminating the freshwater bodies and affecting nontarget organisms.

The physical and chemical changes in aqueous environment often cause some physiological changes in fish, thus, the water quality of an aquatic body is very crucial because it determines the productivity and other parameters necessary for fish survival. Many countries have legislated against the use of chemical poisons in aquatic systems and instead have policies favouring the use of natural bio-degradable alternatives to remove unwanted fish species in aquatic systems. Environmental factors such as $\mathrm{pH}$, turbidity, alkalinity, dissolved oxygen, temperature and conductivity influence the rate of reaction of pollutants entering the water or the lethal effects on the aquatic organisms [ 8 ]. Water temperature affects all aspects of metabolism, and at high temperatures metabolic rate increases; alkalinity, acidity and $\mathrm{pH}$ determine fish health and the well being of fish [9]. Lethal factors restrict the range of the environment in which the organisms can exist and beyond this range, metabolism is destroyed. Controlling and limiting factors both govern metabolic rate while masking and directive factors are exploited by the organisms to achieve and maintain its being through organic regulation [10 ].During the extreme fluctuations of a factor, the organism is exposed to the lethal factor for a short time and its ability to resist the condition would decide its survival [10].

A thin epithelial membrane separates fish blood from the water and any unfavorable change in the water body is reflected in the blood. Environmental pollution and degradation have posed a great problem to aquatic organisms especially fish; the use of natural plants as sedatives in Nigeria is still prevalent due to the lack of practical alternatives. Some researchers have studied the effects of toxicants on haematological changes in fish and Derris has long been used as a toxicant. The exposure of Clarias gariepinus to sub-lethal concentrations of Derris elliptica root was reported to lead to severe alteration in the gills of the fish after $96 \mathrm{~h}$ exposure[11].

This study will report on the haematological changes in the mudfish $C$. gariepinus exposed to sub-lethal concentrations of Derris root powder under laboratory conditions .Clarias gariepinus are freshwater fish found in the tropical regions of West Africa. They are widely distributed in Asia and Africa and they inhabit most lakes, ponds and rivers where they feed mainly on plankton, insects' larvae, snails, crustaceans, worms and small fishes. Clarias species of the family Clariidae is commonly called the "Mudfish" and apart from tilapia, Clarias is the most cultured fish species in Nigeria and are generally strong fish, they possess an accessory respiratory organ, composed of a paired pear shaped air chamber containing two arborescent structures located on the fourth branchial arcs, that are supported by cartilage and covered by highly vascularised tissue which can absorb oxygen directly from the atmosphere. Since the air chamber communicates directly with the pharynx and the gill- chamber, this accessory air breathing organ enables them tolerate adverse aquatic conditions where other cultured fish species can not survive. They grow faster with additional supplementary feed; the demand for the fish is very high due to its oily flesh. They spawn naturally in captivity and their induction is easy In order to control competing species in fish production facilities, control parasites and conserve

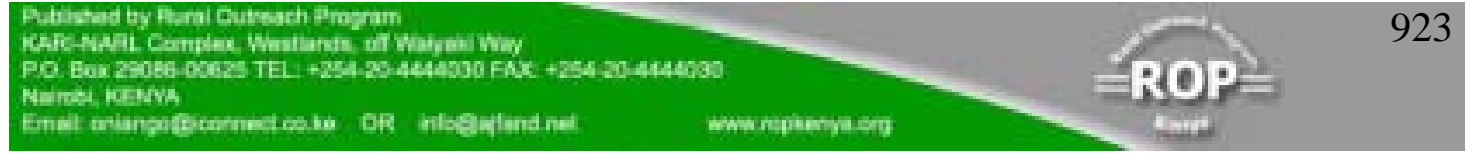


or restore native species, natural plants such as D. elliptica root powder are often used. The use is effective and practical [12 ] but because the chemical is not a selective toxicant, it is inimical to fish and other aquatic organisms.

Many factors such as environmental and physiological are known to influence fish haematology, these include stress due to capturing, transportation, sampling, age and sex. The knowledge of haematological characteristics of the fish is important in determining its health status, toxicological and parasitological investigations as well as selecting brooders for breeding purposes. Haematological studies help in understanding the relationship of blood characteristics to the habitat and adaptability of the species to the environment. The red blood cells count, haematocrit and haemoglobin concentration vary with diet and strain as well as temperature, season of the year and nutritional status of the fish [13]. Chemical and biological analysis of the blood is of considerable value in confirming the diagnosis and response to treatment in a variety of diseases. Haematological studies have been widely used as means of assessing the state of health of fishes and the establishment of the haemotological characteristics of fishes generally serves as a standard for physiology, pathological or toxicological studies. This fish is commonly cultured in several tropical countries of the world and the commercial value of clariid catfish has increased pressure on their population which might result in a decline in catches from their natural habitats if the fishery is left unmanaged. The aim of the study is to report on the haematological changes in the $C$. gariepinus exposed to sub-lethal concentrations of Derris elliptica under laboratory conditions. The paper establishes whether $D$. elliptica root powder as toxicant commonly use by artisanal fishermen during fishing influences the blood parameters of $C$. gariepinus, a fish commonly cultured in several tropical countries of the world.

\section{MATERIALS AND METHODS}

A total of 100 healthy $C$. gariepinus juveniles ( $48 \mathrm{~g}$ ) were used for this study. They were collected from a fish farm in Nigeria and transported to the Fisheries Research laboratory of the Federal University of Technology, Akure, Nigeria. The fish were acclimated to laboratory conditions for a period of 24 hours; during this period, the fish were not fed after which they were randomly distributed into 12 glass tanks $(60 \mathrm{x}$ $40 \mathrm{x} 40 \mathrm{~cm}$ ) containing 20 litres of water at 10 fish per tank. The root of Derris elliptica was used for this study. Derris roots were obtained from Kainji Lake National Park, Nigeria, where they grow naturally; were cleaned, sun-dried for 8 days and milled with a grinding machine. The ground roots were passed through 100 micron sieve to obtain fine powder from the roots. The powder was kept in desiccators. A known weight of the powdered roots $(750 \mathrm{~g})$ was packed into a soxhlet extractor, using ethanol as solvent for the extraction; after the distillation of the solvent, a stock solution of $1000 \mathrm{ml}$ was prepared by adding $150 \mathrm{~g}$ of the ethanolic extract of Derris root powder in 1 litre of water [14]. Tanks A-E received 7.5, 11.0, $15.0,19.0$ and $22.5 \mathrm{~g} / \mathrm{ml}$ of the D. elliptica root powder, respectively. The control group of fish was kept in tank F devoid of the test toxicant $(0.0 \mathrm{~g} / \mathrm{ml})$. Each of these treatments was replicated twice. Ten (10) juveniles of Clarias gariepinus were introduced into 12 aquaria glass tanks which were covered with net to prevent the fish

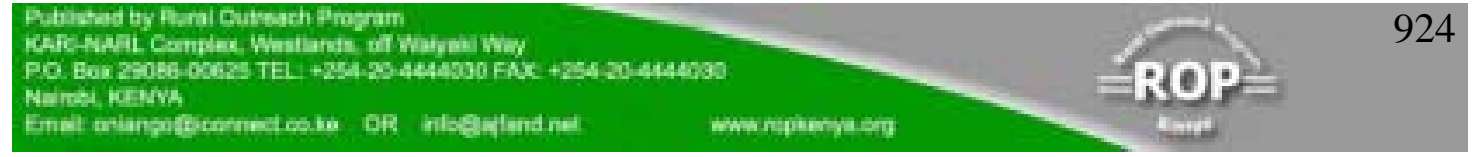


from jumping out. The duration of the experiments was 96 hours. During the 96 hours exposure, temperature, $\mathrm{pH}$, dissolved oxygen, alkalinity of the test media were measured using standard laboratory methods after 3, 6, 12 and $24 \mathrm{hrs}$ daily[15], the $\mathrm{LC}_{50}$ determination was conducted using a modified method [16].The fish were starved in order to minimize waste production and to reduce ammonia production from the wastes during blood collection. No prophylactic treatment was applied and no sexual selection was made. The fish were caught gently individually using a hand net in order to avoid stress; they were anaesthetized and weighed using a Mettler balance; the fish showed no symptoms of stress or diseases. The blood samples were collected from each treatment group. About 5-10ml of blood was collected from the caudal peduncle using separate heparinized disposable syringes containing $0.5 \mathrm{mg}$ ethylene diamine tetra acetic acid (EDTA) as anticoagulant; it was properly mixed and kept in the refrigerator for haematological analysis. PCV was determined thus: heparinized micro-haematocrit capillary tubes were filled with blood and centrifuged for 5 minutes at $15,000 \mathrm{rpm}$. PCV was calculated using a micro-haematocrit reader and it was expressed as a percentage [17]. Haemoglobin concentration was determined using the cyanomethaemoglobin method. Two $\mathrm{ml}$ of blood was pipetted and mixed with the diluent; the mixture was centrifuged to remove suspended cellular materials and the readings were made in a spectrophotometer. Erythrocyte count was made using the methods of [17]; plasma obtained from the samples used in PCV determination, was put into Goldberg's Refractometer (Model 10400A) at $20^{\circ} \mathrm{C}$ and the total plasma protein was determined by direct reading $(\mathrm{gm} / 100 \mathrm{ml})$. Mean cell haemoglobin concentration (MCHC) was calculated by dividing the haemoglobin content in $\mathrm{g} / 100 \mathrm{ml}$ by the PCV/100ml of blood. $(\mathrm{MCH})$ was determined from the haemoglobin value $(\mathrm{Hb})$ and from the erythrocyte count[18].

Results were expressed as mean \pm standard error of mean (SEM) and differences between means were considered to be significant when $\mathrm{P}<0.05$.

\section{RESULTS}

The mean values for the haematological parameters of $C$. gariepinus studies are shown in Table 1. The haematological parameters for the fish at the start of the experiment and those of the fish from the control tanks after $96 \mathrm{~h}$ showed no significant difference. The water quality parameters measured are presented in Table 2 and the various parameters were not significantly different $(P>0.05)$ from each other. The result of the erythrocyte count was higher $\left(43.2 \times 10^{6} / \mathrm{mm}^{3}, 44.3 \times 10^{6} / \mathrm{mm}^{3}\right.$ and $\left.47.50 \times 10^{6} / \mathrm{mm}^{3}\right)$ at the higher concentrations of $D$. ellptica $(15.0,125,19.0 \mathrm{~g} / \mathrm{ml})$ than those of lower concentrations $(7.5$ and $11.0 \mathrm{~g} / \mathrm{ml})$. The correlations between the blood parameters of $C$. gariepinus exposed to D. elliptica root powder solution are presented in Table 3, while the haematological characteristics of $C$. gariepinus at different concentrations of Derris elliptica root powder are presented in Fig. 1. Table 4 shows the results of two replications indicating the percentage mortality of $C$. gariepinus exposed to various acute concentrations of $D$. elliptica root powder and the $\mathrm{LC}_{50}$ at $96 \mathrm{~h}$ was $11.0 \mathrm{~g} / \mathrm{ml}$.

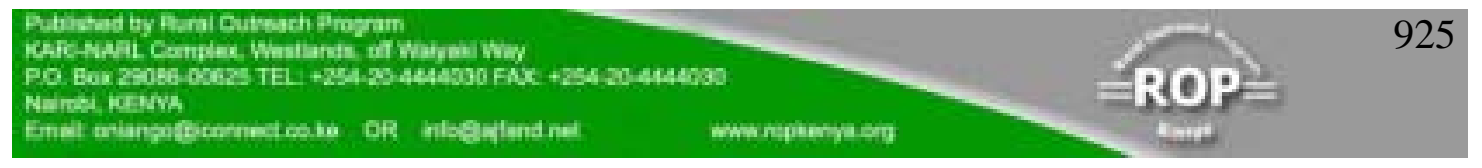




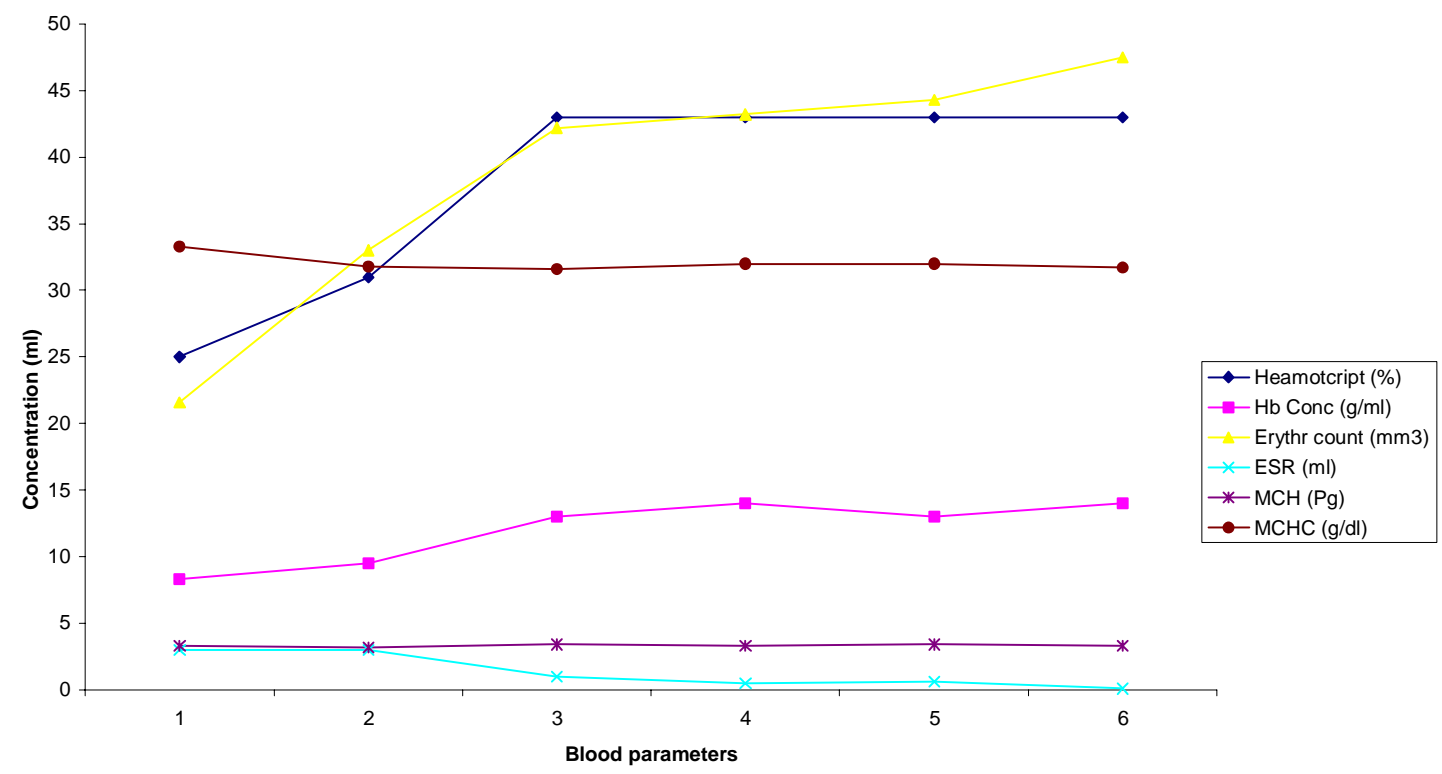

Figure 1:- Haematological characteristics of $C$. gariepinus in five different concentrations $(7.5,11.0,15.0$ and $22.5 \mathrm{~g} / \mathrm{ml})$ of Derris elliptica root powder.

[Note that: $\mathrm{Hb}$ - haemaglobin; ESR - Erythrocyte sedimentation rate , $\mathrm{MCH}$-mean corpuscular haemoglobin, $\mathrm{MCHC}$-mean corpuscular haemoglobin concentration]

\section{DISCUSSION}

Stress factors due to capture, handling and sampling procedures are factors which can cause intra-species haematological variations [19]. Haemoglobin concentration and haematocrit of fish blood decreases after the stress of capture [20] and transportation but the fishes used in this study were kept under laboratory conditions.

The non significant changes in the water parameters of various experimental media reported in this study showed that the sub-lethal concentrations of Derris elliptica did not adversely lead to reduction in water quality where slight changes were observed; the values were within normal range of fish tolerance.

Exposure of $C$. gariepinus to sub-lethal concentrations of D. elliptica caused a significant increase in PCV, haemoglobin, and erythrocyte of the fish. Packed Cell Volume increased with the high concentrations of Derris elliptica $(19.0,22.5 \mathrm{~g} / \mathrm{ml})$, indicating positive absorption of D. elliptica root powder solution by the fish. PCV could be used to detect haemolysis [21] and is used as a tool for checking anaemic 
condition in fishes; PCV values are usually between $20 \%$ and $35 \%$ and scarcely attain values greater than 50\% [22]. Mean PCV values in this study fell within this range and were similar to those of $H$. longifilis [23].

Haemoglobin concentration and erythrocyte counts increased with increasing concentration of $D$. elliptica root powder. In fish blood, oxygen is carried in combination with haemoglobin and this is very important for the survival of the fish. The mean haemoglobin values of $C$. gariepinus in this study were close to values reported for $H$. longifilis [23]. Erythrocyte Sedimentation Rate decreased with increasing $D$. elliptica concentrations and has been used to ascertain the response of fish blood to stress, pollution, diseases, starvation and nutritional deficiency [24]. Mean corpuscular haemoglobin concentration (MCHC) values reported for Oreochromis niloticus, Heterobranchus bidorsalis and other African fishes were comparable to those of $C$. gariepinus [25].

The blood parameters observed were similar to those reported for H. bidorsalis [25]. The direct proportion between the value of PCV, ESR and $\mathrm{Hb}$ of $C$. gariepinus showed that the increase in PCV increased the $\mathrm{Hb}$ concentration in the blood of the fish. There was positive correlation between erythrocyte count and ESR while there was negative correlation between $\mathrm{PCV}, \mathrm{Hb}, \mathrm{MCH}$ in $C$. gariepinus exposed to different concentrations of $D$. elliptica root powder.

Sub-lethal concentrations of toxicants in the aquatic environment will not necessarily result in outright mortality of aquatic organisms. They have significant effects which can result in several physiological dysfunction in the fish. The use of Derris in aquaculture is currently being discouraged in developed countries due to its toxicity at higher concentrations. The result from this study reveals high mortality rate and deleterious consequences on the health of fish subjected to acute exposure of Derris and therefore, should not be used for any purpose in aquaculture at concentration higher than $11.0 \mathrm{~g} / \mathrm{ml}$.

\section{ACKNOWLEDGMENTS}

This research was funded by International Foundation for Science (IFS) Sweden under IFS Grant No. A/356-1 and Organization for the Prohibition of Chemical Weapons (OPCW) . 
Table 1: Mean Value of haematological parameters of C. gariepinus juveniles exposed to at different concentration of $D$. elliptica for 96 hours.

\begin{tabular}{lllllll}
\hline $\begin{array}{l}\text { Haematological } \\
\text { Parameters }\end{array}$ & \multicolumn{5}{c}{ D.. elliptica concentrations $(\mathrm{ml})$} \\
& $0.0 \mathrm{ml}$ & $7.5 \mathrm{~g} / \mathrm{ml}$ & $11.0 \mathrm{~g} / \mathrm{ml}$ & $15.0 \mathrm{~g} / \mathrm{ml}$ & $19.0 \mathrm{~g} / \mathrm{ml}$ & $22.5 \mathrm{~g} / \mathrm{ml}$ \\
\cline { 2 - 7 } & & & & & & \\
Haematocrit & $2500 \pm$ & $31.00 \pm 0.20$ & $43.20 \pm 0.42$ & $43.00 \pm 0.80$ & $43.40 \pm 0.38$ & $45.20 \pm 0.35$ \\
(PCV) & 0.00 & & & & & \\
Haemoglobin & $8.30 \pm 0.00$ & $9.50 \pm 0.00$ & $13.00 \pm 0.20$ & $14.00 \pm 0.43$ & $13.60 \pm 0.11$ & $14.40 \pm 0.10$ \\
Con. (Hb) & & & & & & \\
Erythrocyte count & $21.60 \pm$ & $33.00 \pm 0.10$ & $42.20 \pm 0.10$ & $43.20 \pm 0.40$ & $44.30 \pm 0.40$ & $47.50 \pm 0.58$ \\
& 0.00 & & & & & \\
ESR & $3.00 \pm 0.00$ & $3.00 \pm 0.00$ & $1.00 \pm 0.000$ & $0.50 \pm 0.00$ & $0.60 \pm 0.00$ & $0.10 \pm 0.00$ \\
MCH & $3.30 \pm 0.00$ & $3.20 \pm 0.10$ & $3.40 \pm 0.20$ & $3.30 \pm 0.10$ & $3.40 \pm 0.20$ & $3.30 \pm 0.10$ \\
MCHC & $33.30 \pm$ & $31.80 \pm 0.40$ & $31.60 \pm 0.12$ & $32.00 \pm 0.47$ & $32.00 \pm 0.42$ & $31.70 \pm 0.15$ \\
& 0.00 & & & & & \\
& & & & & & \\
\hline
\end{tabular}

*Mean value with standard deviation $( \pm$ SD)

Legend:

PCV - packed cell volume

$\mathrm{Hb}$ - haemaglobin

MCHC - mean corpuscular haemoglobin concentration

ESR = Erythrocyte Sedimentation rate in $\mathrm{mm} / \mathrm{hr}$

$\mathrm{MCH}=$ Mean Corpuscular haemoglobin $(\mathrm{Pg})$

$\mathrm{MCHC}=$ Mean Corpuscular haemoglobin concentration in $\mathrm{g} / \mathrm{dl}$ 
Table 2: $\quad$ Water Quality Parameters Values* obtained during exposure of the $C$. gariepinus to sub-lethal concentrations of Derris elliptica for 96 hours.

\begin{tabular}{lcc}
\hline Water Parameter & \multicolumn{2}{c}{ Mean \pm S.D $(\mathrm{n}=4)$} \\
\hline Temperature $\left({ }^{\circ} \mathrm{C}\right)$ & $27.00 \pm 0.00$ & $27.5 \pm 0.00$ \\
Dissolved oxygen $\left(\mathrm{Mg} l^{-1}\right)$ & $4.60 \pm 0.00$ & $4.60 \pm 0.00$ \\
$\mathrm{Ph}$ & $7.68 \pm 0.00$ & $7.70 \pm 0.00$ \\
\hline
\end{tabular}

*Each data is an average of 5 determinations

Table 3 : $\quad$ Correlation coefficients between blood parameters of $C$. gariepinus at different concentrations of D. elliptica root powder during 96 hours exposure.

\begin{tabular}{lrrrrrr}
\hline & \multicolumn{1}{c}{$\mathrm{PCV}$} & $\mathrm{Hb}$ & erythrocytes & ESR & $\mathrm{MCH}$ & $\mathrm{MCHC}$ \\
\hline PCV & 1 & & & & & \\
Hb & 0.9876 & 1 & & & & \\
Erythrocytes & 0.9824 & 0.9665 & 1 & & & \\
ESR & -0.9617 & -0.9876 & -0.9239 & 1 & & \\
MCH & 0.5359 & 0.4881 & 0.4107 & -0.5282 & 1 & \\
MCHC & -0.7587 & -0.6764 & -0.8276 & 0.5686 & -0.167 & 1 \\
\hline
\end{tabular}

Legend:

PCV - packed cell volume

$\mathrm{Hb}$ - haemaglobin

MCHC - mean corpuscular haemoglobin concentration

$\mathrm{ESR}=$ Erythrocyte Sedimentation rate in $\mathrm{mm} / \mathrm{hr}$

$\mathrm{MCH}=$ Mean Corpuscular haemoglobin $(\mathrm{Pg})$

$\mathrm{MCHC}=$ Mean Corpuscular haemoglobin concentration in $\mathrm{g} / \mathrm{dl}$ 


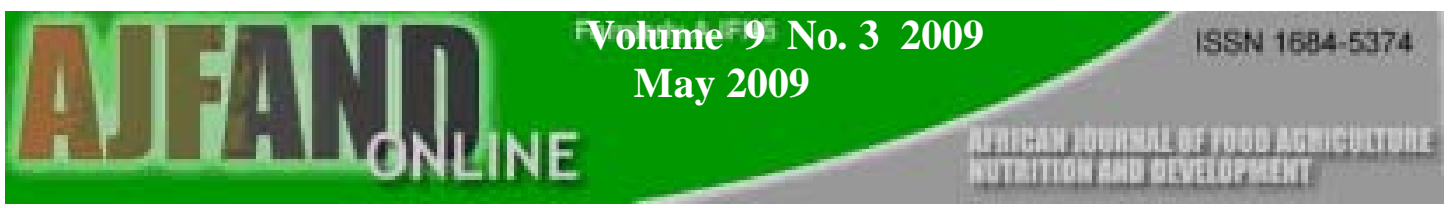

Table 4: $\quad$ Percentage Mortality $\left(\mathrm{LC}_{50}\right)$ of $C$. gariepinus exposed to various acute concentrations of root powder of $D$. elliptica .

\begin{tabular}{|c|c|c|c|c|c|}
\hline \multirow[t]{2}{*}{ Concentration (g/ml) } & \multicolumn{4}{|c|}{ Mortality } & \multirow{2}{*}{$\begin{array}{c}\text { Average } \\
\text { percentage } \\
\text { of } \\
\text { mortality } \\
(\%) \\
\end{array}$} \\
\hline & $24 \mathrm{~h}$ & $48 \mathrm{~h}$ & $72 \mathrm{~h}$ & $96 \mathrm{~h}$ & \\
\hline Control (0.0) & - & - & - & - & 0 \\
\hline 7.5 & - & - & - & - & 0 \\
\hline 11.0 & - & 2 & 4 & 4 & 20 \\
\hline 15.0 & 4 & 8 & 8 & 10 & 50 \\
\hline 19.0 & 6 & 10 & 16 & 16 & 80 \\
\hline 22.5 & 10 & 16 & 18 & 20 & 100 \\
\hline
\end{tabular}

N. B. Results of 2 replications over 96 hours 


\section{REFERENCES}

1. McClay W Rotenone use in north America (1988-1997).Fisheries 2000; 25(5): $15-21$.

2. Wang D and JB Huffman Botanochemicals supplements to petrochemicals Economic Botany1991: 35(4): 369-382.

3 Warren D Biology and water pollution control .W .B Saunder company, Philadelphia, Fish Edition. 1977: 24-39.

4 Jennes $\mathbf{J}$ The use of plants as fish poison within the Kanji basin. In: Reed W (Ed). Fish and fisheries of Northern Nigeria. Ministry of Agriculture of Nigeria. 1967: p 226.

5. Duke JA Handbook of legumes of world economic importance. Plenum Press, New York 1983, p 345.

6. Baird $\mathbf{F}$ Pest control in tropical aquaculture .An ecological hazard assessment of natural synthetic control agents. Mitteilungen International Verein Limnologie 1994; 24: 285-292.

7. Tumanda $M$ Effects of rotenone containing Derris root extracts on the mortality of some predator fishes of pond cultured prawns under different water temperature salinity combinations. M.S thesis. University of San Carlos, Cebu City, Philippines 1980, p 89.

8. Fagbenro OA Tilapia Fish for thought Inaugural Lecture Series 32. Federal University of Technology, Akure 2002; p 77

9. Ross B and LG Ross Anaesthetic and Seductive for Aquatic Animals. $2^{\text {nd }}$ Edition, Blackwell Science Ltd, 2002

10. Omozusi BB , Fagbenro OA and OT Adebayo Toxicity of alkaline salt ( trona) to hybrid catfish (clarias gariepinus $\times$ Heterobranchus bidorsalis) fingerlings. European Aquaculture Society, Special Publication Oostende, Belgium 2000, 28: 525 .

11 Akinbulumo MO, Fagbenro OA and EA Fasakin Acute toxicity of ethanolic extract of Derris elliptica roots to African catfish (Clarias gariepinus, Burchell, 1822) fingerlings. Biological and Environmental Sciences Journal of the Tropics (BEST) 2005 ; 2: 126 -131.

12 Guerrero RD and LA Guerrero Use of Derris root powder for management of freshwater ponds. Aquatic Biosystems, Bay, Laguna,Philippines.1986, p 121 -124 . 
13. Barnhart RA Effects of certain variables on the haematological characteristic of rainbow trout. Trans. Amer. Fish. Soc. 1969; 98: p 411-418.

14. Olaiya FE, Olaiya AK and OO Lewis Toxic stress of lead on Clarias gariepinus (African catfish fingerlings) Afri J. of Biochem. Res. 2003; 6: 101 104.

15. APHA, AWWA and WPCF (American Public Health Association, American Water Works Association and Water Pollution Control Federation): Standard Method for the Examination of Water and Waste Water. $17^{\text {th }}$ Edition. APHA, Washington, D.C. 1989, p 1391.

16. Lorke D A new approach to acute toxicity testing. Arch.Toxicol.1983; $54: 275$ 287.

17. Svobodova Z, Pravda D and J Palackova Unified Methods of haematological examination of fish. Research Inst. Of Fish Culture and hydrobiology Vodnany, Czecholovakia, 1991, p 31.

18. Bouck RG and RC Ball Influence of capture methods on blood characteristics and mortality in rainbow trout (Salmo gardneri) Trans Am. Fish Soc. 1966; p 167-176.

19. Hattingh $\mathbf{J}$ and AJJ Van Pletzen The influence of capture and transportation on some blood parameter of freshwater fish. Comp. Brochem physcol.1974; 49a: 607-609.

20 Archer RK and LB Jeffcott. Comparative clinical haematology. Blackwell Scientific Publishers. 1977.

21. Clark S, Whitemore DH Jr and RF McMahon. Consideration of blood parameters of largemouth bass Micropterus salmoides J. Fish Bio. 1979; 14: $147-154$.

22. Erondu ES, Nnubia $\mathbf{C}$ and $\mathbf{O}$ Nwadukwe. Haematological studies on four catfish species raised in freshwater ponds in Nigeria. J. Applied Ichth. 1993; 9: $250-256$.

23. Wedemeyer GT and WT Yasutake. Clinical methods for the assessment of the effect of environmental stress on fish health. Technical Report, U.S fish and Wildlife Service. 1977; 89, p 17.

24. Omoeregie E, Ufodike EBC and IR Keke. Tissue chemistry of Orechromis niloticus exposed to sublethal concentrations of gammalin 20 and actellic 25 . Ec. J. Aq. Sci. 1990; 5: $33-36$. 


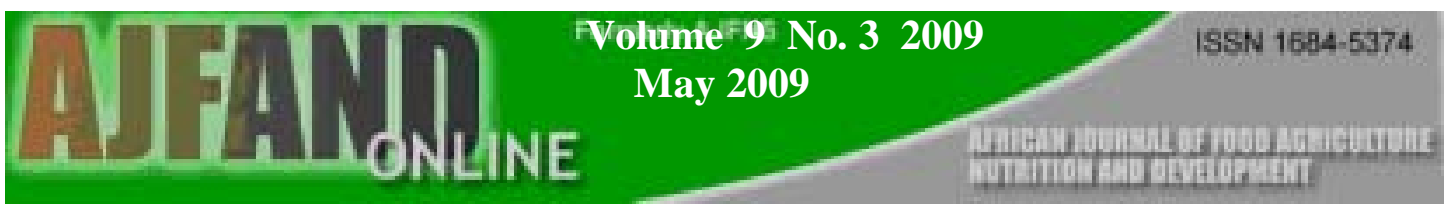

25. Fagbenro OA, Adedire CO, Owoseni EA and EO Ayotunde. Studies on the biology and aquacultural potential of feral catfish, Heterobranchus bidorsalis( Geoffory St. Hilaire 1809). (Clariidae). Tro . Zoo. 1993: 6: 67-69. 